\title{
Ant-diaspore interactions during secondary succession in the Atlantic forest of Brazil
}

Victor P. Zwiener ${ }^{1,2}$, Jochen H. Bihn ${ }^{3}$ \& Márcia C. M. Marques ${ }^{2}$

1. Society for Wildlife Research and Environmental Education (SPVS). Rua Isaias Bevilacqua, 999, 80430-040, Curitiba, Paraná, Brazil; vzwiener@gmail.com

2. Universidade Federal do Paraná, Setor de Ciências Biológicas, Departamento de Botânica, Caixa Postal 19.031, 81531-980 Curitiba, Paraná, Brazil; mmarques@ufpr.br

3. Department of Ecology - Animal Ecology, Philipps-Universität Marburg, Karl-von-Frisch Straße 8, 35032 Marburg, Germany; jochen.bihn@gmail.com

Received 25-IV-2011. Corrected 06-X-2011. Accepted 02-XI-2011.

\begin{abstract}
Animal-plant interactions are important for the recovery of diversity and processes in secondary forests, which increasingly dominate the tropical landscape. We used a combination of observational and experimental approaches to study the interactions of ants with diaspores across a successional gradient of forests in Southern Brazil, from August 2007 to April 2008. In addition to diaspore removal rates, we assessed the species richness, diversity and behaviour of ants interacting with diaspores, in three replicated sites of four successional stages of forests. We recorded 22 ant species interacting with diaspores (an estimated $15 \%$ of the total species pool in the region). Species richness and diversity did not differ among successional stages but the behaviour of ants towards diaspores changed with the age of secondary forests. In old successional stages the removal of entire diaspores was more common than in young successional stages of forests. Concordantly, diaspore removal rates were lowest in the youngest successional stage of secondary forests and increased with the age of forests. These results indicate that ant-diaspore interactions in secondary forests are disturbed and lower removal rates in secondary forests are likely to constrain the recruitment of plant populations during secondary succession. Rev. Biol. Trop. 60 (2): 933-942. Epub 2012 June 01.
\end{abstract}

Key words: ant-plant interactions, forest recovery, seed dispersal, seed predation, succession, tropical secondary forests.

Tropical old-growth forests are vanishing at alarming rates and are converted into pastures and agricultural lands (Wright 2005, Chazdon et al. 2009). The total area covered by forests, however, is increasing in tropical countries across the globe (Wright \& MullerLandau 2006). This situation arises because of secondary forests, regenerating on former agricultural land increasingly dominate the tropical landscape (FAO 2007). Animal-plant interactions are important for the recovery of diversity and ecological processes in secondary forests (Guariguata \& Ostertag 2001, Chazdon 2003). Secondary forests emerging in human-impacted landscapes do not match the original old-growth forests in species composition (Hobbs et al. 2006). Therefore, it is still uncertain to what extent secondary forests will maintain similar processes with respect to new combinations of species.

Most plants in tropical forests produce diaspores (fruits, seeds) adapted for animal dispersal (Frankie et al. 1974, Howe \& Smallwood 1982). Both seed dispersal and seed predation are important ecological processes during forest regeneration as they influence the spatial distribution and survival of seedlings, and ultimately the structure of plant communities (Hulme 1998, Guariguata \& Ostertag 2001, Wang \& Smith 2002). The disruption of 
these processes may have serious consequences for tropical forest regeneration. For instance, the extinction of animal dispersers in secondary forests can lead to arrested succession (Sarmiento 1997, Holl 2000), or even to cascading co-extinctions (Koh et al. 2004). Thus, a better understanding of how these ecological processes recover during the regeneration of tropical forests is an important step toward conservation and management of these forests (Guariguata \& Ostertag 2001).

Ants (Hymenoptera: Formicidae) are important dispersers and predators of diaspores in tropical forests (Levey \& Byrne 1993, Pizo \& Oliveira 2000, Passos \& Oliveira 2003). Ants contribute to the plant reproductive cycle by transporting fallen diaspores from the forest floor or acting as secondary dispersers transporting diaspores from vertebrate feces into their nests, where they either store them or remove the remaining fleshy pulp for consumption and afterwards discard the seeds in refuse piles (Beattie 1985, Kaspari 1993, Vander Wall \& Logland 2004, Rico-Gray \& Oliveira 2007). Ants may also remove the fleshy part of diaspores in situ promoting better conditions for germination and establishment of seedlings (Ohkawara \& Akino 2005). The diversity of ground foraging ants in secondary forests is often lower than in old-growth forests (Dunn 2004, Silva et al. 2007) and we found the same diversity pattern of ants for the Atlantic forest in Southern Brazil (Bihn et al. 2008). The interactions between ants and non-myrmecochorous diaspores in tropical forests are mostly not species specific, i.e. ants interact with diaspores of many plant species and vice versa (Pizo \& Oliveira 2000, Passos \& Oliveira 2003). Thus, the reduced species diversity of ants in secondary forests might have no consequences for the interactions between ants and diaspores as long as a minimum subset of species that interact with diaspores is retained in secondary forests. Instead, the rate of seed removal and dispersal by ants might be a function of ant activity and relative abundance (Gove et al. 2007, Manzaneda \& Rey 2008, Zelikova \& Breed 2008). In the Atlantic forest of Southern Brazil
(Bihn et al. 2008) and in other tropical forests (Armbrecht et al. 2004, Silva et al. 2007), the abundance of ant species increases with successional age of forests. Thus, each diaspore on the ground of mature tropical forests might have a higher chance of being encountered, removed and possibly dispersed by ants, than diaspores on the ground of early successional stages of secondary forests. Therefore, we expected that diaspore removal rates are highest in old-growth forest and will increase with increasing age of secondary forests.

We used a combination of experimental and observational approaches to study shifts in ant-diaspore interactions across a successional gradient in the Atlantic Forest of Southern Brazil. Exclosure experiments were used to estimate rates of diaspore removal in secondary forests differing in age since abandonment, and in old-growth forests. Additionally, we assessed the diversity and behaviour of ants interacting with diaspores on the forest floor in different successional stages of forests.

\section{MATERIALS AND METHODS}

Study region and sites: Field studies were conducted at the Rio Cachoeira Nature Reserve $\left(25^{\circ} 18^{\prime} 51^{\prime \prime} \mathrm{S}-48^{\circ} 41^{\prime} 45^{\prime \prime} \mathrm{W}\right)$ in the state of Paraná, Southern Brazil, from August 2007April 2008. The regional climate is classified as humid sub-tropical (Köppen's Cfa). The area receives an annual rainfall of $2600 \mathrm{~mm}$ without a marked dry season, less rain occurs between May and August. The mean temperature varies between $16.2^{\circ} \mathrm{C}$ in July and $24.5^{\circ} \mathrm{C}$ in February (IPARDES 1991). Tropical lowland and submontane forests originally covered the area, but these suffered intense exploitation and large portions had been converted to pastures. The resulting landscape mosaic consisted of recently abandoned pastures, secondary forests in various stages of succession, and old-growth forests (Ferretti \& Britez 2006).

The experiments were carried out in four successional stages: secondary forests of 9-11years, 15-20years, and 40-55years since abandonment of pastures, and old-growth 
forests (sensu Clark 1996). Old-growth forests had not been logged for at least 100 years. Three study sites were selected for each successional stage. Land-use history for study sites was established through interviews with residents and reserve staff corroborated by inspection of high resolution, geocoded orthophotos from the years 1952, 1980 and 2002 in a GIS environment. Replicated sites of a particular successional stage were separated by an average distance of $4 \mathrm{~km}$ (range: 1-6km). Study plots were never situated in one continuous patch of the same vegetation type, but separated by areas of different successional stages, pastures, among others (Bihn et al. 2008 for a map of the reserve and the location of the study sites within it).

Ant-diaspore interactions: To determine which ants interact with diaspores on the forest floor, as well as how they interact with diaspores, we made observations at experimental diaspore depots, mimicking clumps of dispersed diaspores. In March and April 2008 we established five experimental diaspore depots, separated by a minimum of $10 \mathrm{~m}$, in each study site. Diaspore depots consisted of 30 diaspores of three tree species (10 diaspores of each species) placed on a plastic plate $(8.5 \mathrm{~cm}$ diameter $)$ on the forest floor. Diaspores were collected in the study region from at least three different fruiting individuals during their natural dispersal period and were from the following species: Pera glabrata (Schott) Baill. , Hyeronima alchorneoides M. Allemão and Trema micrantha (L.) Blume. We used only diaspores collected on the same day in our experiments because stored diaspores or diaspores that had been refrigerated could suffer from desiccation and chilling injuries thus changing some of their characteristics and introducing bias (Theilade \& Petri 2003). The plant species were selected because they were fruiting during the study period, were common in the study area and are known to be attractive to ants (Pizo \& Oliveira 2000, Passos \& Oliveira 2003), which we confirmed in preliminary experiments. The selected species are canopy trees, fruiting from January to April, their diaspores are primarily dispersed by birds and they have a wide distribution within the reserve and the Atlantic Forest. P. glabrata fruits consist of a dry unpalatable outer covering that splits when mature exposing three to four diaspores. The diaspores consist of brilliant black seeds $(3 \mathrm{~mm}$ diameter, 0.02g fresh weight; Passos \& Oliveira 2003), which are partially surrounded by a cuplike, red, fleshy, aril-like endocarp. H. alchorneoides has roundish fruits $(8 \mathrm{~mm}$ diameter, 0.04g fresh weight; Flores 1993) consisting of a reddish fleshy pulp and one single seed. T. micrantha fruits are the smallest fruits used in the experiment $(3 \mathrm{~mm}$ diameter, $0.01 \mathrm{~g}$ fresh weight; Silveira et al. 2003). The fruit consists of a green fleshy pulp that turns orange when mature and encase a single seed.

Observations at diaspore depots were made between 10:00 and 14:00. Each diaspore depot was checked after 15, 30, 45, 60, 75 and $90 \mathrm{~min}$. The species and the abundance of ants interacting with diaspores were recorded as well as their behaviour towards the diaspores. To determine whether the species richness and the diversity of ants interacting with diaspores increases during secondary forest succession, we applied a Poisson generalized linear model (GLM) with a logarithmic link function in the analysis of ant species richness among successional stages. In the analysis of the diversity of ants interacting with diaspores we calculated the Shannon-Weiner diversity index (H') and evenness $\left(E_{H}\right)$ (Krebs 1989), the diversity and evenness of ants were tested with a Gaussian generalized linear model (GLM).

The behaviour of ants interacting with diaspores was classified as "seed cleaning" (one or more ants removing the fleshy part of diaspores, but the diaspore is not removed) or "removal of diaspores" (one or more ants removing diaspores from the depot). For each ant species recorded we counted the number of stations where we observed these ant-diaspore interactions. Then we summed up the number of behaviour observations for each successional stage. Because the frequency of observations was low for some combinations of behaviour 
and successional stage, we pooled the frequencies of the two youngest and the two oldest successional stages. To determine whether the behaviour of ants towards diaspores differed among successional stages we compared the rates of the two behaviours with Fisher's Exact test. Voucher specimens of ants were collected, identified to species/morphospecies and deposited at the Coleção Entomológica Padre Jesus Santiago Moure, Departamento de Zoologia, Universidade Federal do Paraná, Brazil (DZUP).

Diaspore removal experiment: Rates of diaspore removal by ants in different successional stages were measured in an exclusion experiment. At each site we set up 10 sampling stations separated by a minimum of $10 \mathrm{~m}$. At each station we placed one plastic plate $(8.5 \mathrm{~cm}$ in diameter) with $1 \mathrm{~g}$ of milled Tartary buckwheat seeds (Fagopyrum tataricum (L.) Gaertn.). Seed fragments ranged from 1-4mm in diameter and had a mean dry mass of $12 \mathrm{mg} \pm 1 \mathrm{SE}(\mathrm{n}=50)$. We used relatively small seed sizes because the removal of small diaspores is not constrained by the size of the ant but large diaspores tend to be removed only by larger ants (Pfeiffer et al. 2006). As in many other seed removal experiments worldwide (Thompson et al. 1991, Christianini \& Galetti 2007) we used diaspores that are not native to the study region. Diaspores of native species were not used due to the large amount of diaspores needed in order to replicate the experiment across all sites and successional stages and because native diaspores were not available during two seasons of the year (summer and winter). In preliminary diaspore removal trials we confirmed that seed fragments of Tartary buckwheat were attractive to ants. Thus, we could assess diaspore removal rates in an unbiased way across different stages of forest succession and across two seasons.

Plates were covered with a wire cage $(15 \mathrm{~cm} \times 15 \mathrm{~cm} \times 15 \mathrm{~cm}, 1 \mathrm{~cm}$ mesh size) to exclude vertebrates but allowing ants to access the diaspores. Cages were secured to the ground with wire anchors. We placed a transparent plastic cover over each plate to prevent the diaspores from being washed away by rain. Sampling stations were placed at least $50 \mathrm{~m}$ from trails, or any other different habitat (e.g. forest gaps) to reduce edge effects. We placed $1 \mathrm{~g}$ of diaspores on each plate, arranged in a pile of $\sim 1 \mathrm{~cm}$ in diameter. After $48 \mathrm{hr}$ diaspores were carefully collected into plastic bags, ovendried (at $60^{\circ} \mathrm{C}$ for three days) and reweighted. We used the difference in weight as a measure of diaspores removed. Diaspore removal trials were performed in August 2007 (winter) and March 2008 (summer). Sampling stations were placed at different locations within sites during winter and summer sampling. To reduce possible variation in diaspore removal due to weather conditions, we performed experiments in one site of each successional stage on the same day. Trials were performed in the absence of heavy rain.

Diaspore removal rates were analyzed with a two-factor nested ANOVA. The main factor in this analysis was "successional stage" (fixed factor; levels: 9-11yr, 15-20yr, 40-55yr, >100yr) with three "sites" (random factor) nested within each level of the main factor and 20 replicated observations for each combination of "successional stage" and "site". We tested for a linear trend in changes of diaspore removal along the successional gradient employing polynomial contrast coefficients that were coded according to the age of the successional forest stages. Data on diaspore removal were $\log 10$-transformed prior to analysis to reduce skewness of the distribution.

\section{RESULTS}

Ants interacting with diaspores: We found ants interacting with diaspores at 56 of 60 diaspore depots. Ants discovered diaspores rapidly and in the majority of cases we observed interactions within $15 \mathrm{~min}$. after exposure of diaspores. We recorded 22 ant species from seven genera and four subfamilies interacting with diaspores at depots (Table 1). Species richness of ants did not differ among successional stages (GLM: $\mathrm{p}=0.32$ ). We recorded 2.7 
TABLE 1

Ant species interacting with diaspores in different successional stages of forests (years since abandonment of pastures). Species occurrence in each successional stage is indicated by an " $\mathrm{X}$ "

\begin{tabular}{|c|c|c|c|c|}
\hline \multirow{2}{*}{ Ant species } & \multicolumn{4}{|c|}{ Successional stage } \\
\hline & $9-11 \mathrm{yr}$ & $15-20 \mathrm{yr}$ & $40-55 \mathrm{yr}$ & $>100 \mathrm{yr}$ \\
\hline \multicolumn{5}{|l|}{ Dolichoderinae } \\
\hline Linepithema pulex Wild 2007 & & & $\mathrm{X}$ & \\
\hline \multicolumn{5}{|l|}{ Ectatomminae } \\
\hline Gnamptogenys striatula Mayr 1883 & & & $\mathrm{X}$ & \\
\hline \multicolumn{5}{|l|}{ Myrmicinae } \\
\hline Crematogaster JHB02 & $X$ & $X$ & $\mathrm{X}$ & \\
\hline Pheidole cf. ambigua Wilson 2003 & & $\mathrm{X}$ & $X$ & \\
\hline Pheidole cf. synarmata Wilson 2003 & $X$ & $\mathrm{X}$ & & \\
\hline Pheidole gibba Mayr 1887 & & & & $X$ \\
\hline Pheidole lucretii Santschi 1923 & & & $\mathrm{X}$ & $X$ \\
\hline Pheidole JHB01 & & & & $\mathrm{X}$ \\
\hline Pheidole JHB02 & $\mathrm{X}$ & & & $X$ \\
\hline Pheidole JHB03 & & $X$ & $\mathrm{X}$ & $X$ \\
\hline Pheidole JHB08 & & & $\mathrm{X}$ & $\mathrm{X}$ \\
\hline Pheidole JHB11 & & & $\mathrm{X}$ & \\
\hline Pheidole JHB14 & $X$ & & & \\
\hline Pheidole JHB19 & $\mathrm{X}$ & $X$ & $\mathrm{X}$ & $\mathrm{X}$ \\
\hline Pheidole JHB22 & & & $\mathrm{X}$ & \\
\hline Pheidole JHB024 & & & $\mathrm{X}$ & \\
\hline Solenopsis JHB03 & & & & $\mathrm{X}$ \\
\hline Solenopsis JHB08 & & $\mathrm{X}$ & $\mathrm{X}$ & $X$ \\
\hline Solenopsis JHB09 & & $\mathrm{X}$ & & \\
\hline Wasmannia auropunctata (Roger 1863) & $X$ & $\mathrm{X}$ & & \\
\hline Wasmannia JHB02 & & & & $\mathrm{X}$ \\
\hline \multicolumn{5}{|l|}{ Ponerinae } \\
\hline Pachycondyla striata (Smith 1858) & $X$ & $X$ & & \\
\hline
\end{tabular}

$( \pm 1.2 \mathrm{SE})$ species in study sites of 9-11years old secondary forests, $4.3( \pm 0.9$ SE) species in 15-20years secondary forests, $5.7( \pm 1.5 \mathrm{SE})$ species in 40-55years old secondary forests, and $3.7( \pm 0.9 \mathrm{SE})$ species in old growth forests $(n=3$ for each mean).

The diversity and evenness of ants interacting with diaspores did not differ across the successional gradient (GLM: $\mathrm{p}=0.30$ and $\mathrm{p}=0.19$, respectively). In secondary forests of $9-11 \mathrm{yr}$, $\mathrm{H}^{\prime}=0.74( \pm 0.5 \mathrm{SE})$ and $\mathrm{E}_{\mathrm{H}}=0.97( \pm 0.02 \mathrm{SE})$, in $15-20 \mathrm{yr}$ secondary forests $\mathrm{H}^{\prime}=1.36( \pm 0.2 \mathrm{SE})$ and $\mathrm{E}_{\mathrm{H}}=0.95( \pm 0.01 \mathrm{SE})$, in 40-55yr secondary forests $\mathrm{H}^{\prime}=1.53( \pm 0.2 \mathrm{SE})$ and $\mathrm{E}_{\mathrm{H}}=0.93( \pm 0.01$ $\mathrm{SE})$ and $\mathrm{H}^{\prime}=1.13( \pm 0.3 \mathrm{SE})$ and $\mathrm{E}_{\mathrm{H}}=0.91( \pm 0.03$ $\mathrm{SE}$ ) in old growth forests ( $\mathrm{n}=3$ for each mean).
In all successional stages "seed cleaning" was the most frequent behaviour of ants interacting with diaspores. Nevertheless, the proportion of seed depots where we observed ants removing diaspores increased from 19\% in the youngest successional stages to $38 \%$ in the oldest successional stages (Fig. 1). This difference in the frequency of ant behaviour towards diaspores was significant (Fisher's Exact test, $\mathrm{p}=0.049$ ).

Diaspore removal rates: Diaspore removal rates in the 12 study sites varied from $22 \%-61 \%$ depending on successional stage. In general, removal rates increased with an increase in age of successional stage (Fig. 2; 


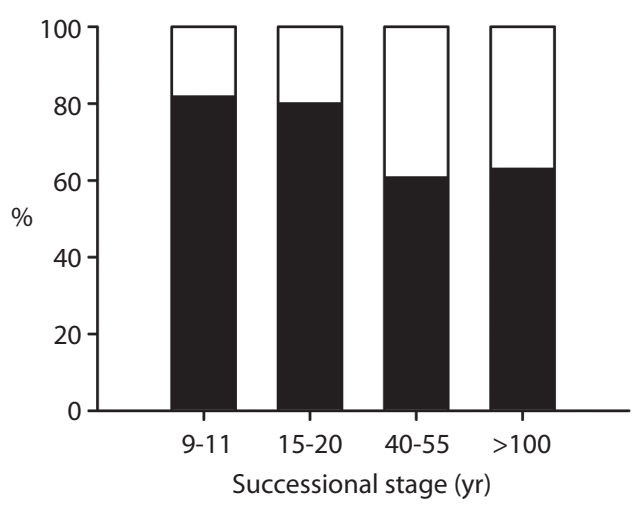

Fig. 1. Relative frequency of different behaviours of ants at diaspore depots: white bars: removal of diaspores; black bars: seed cleaning. Note that the values refer to the total number of events.

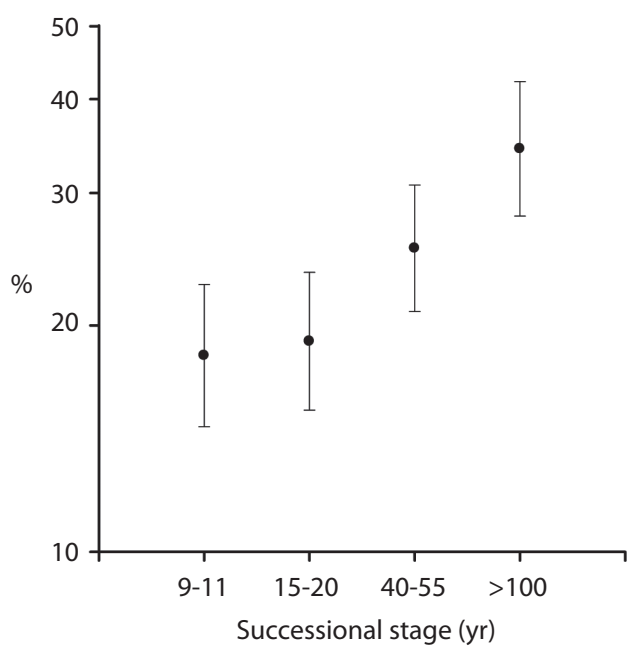

Fig. 2. Diaspore removal rates by ants in forests differing in successional age (years since abandonment of pastures; $\mathrm{n}=3$ for each successional stage). The error bars represent $\pm 1 \mathrm{SE}$.
Table 2). Average diaspore removal rates in old growth forests $(45 \%)$ were higher than in $40-55 \mathrm{yr}, 15-20 \mathrm{yr}$ and $9-11 \mathrm{yr}$ forests $(33 \% ; 26 \%$ and $25 \%$, respectively). Diaspore removal in old growth forest was 1.8 times higher than in the $9-11$ yr forest.

\section{DISCUSSION}

Animal-diaspore interactions play an important role in the dynamics of tropical forests and their disruption may have negative consequences for forest regeneration. We found no changes in the richness of ants interacting with diaspores along a gradient of forest succession in the Atlantic forest of Southern Brazil. However, the behaviour of ants interacting with diaspores changed along the successional gradient, "diaspore removal" was more frequent in older successional stages. Concordantly, diaspore removal rates, assessed in the removal experiment, were lower in secondary forests than in old-growth forests. These changes in the interactions between ants and diaspores are likely to have implications for the population dynamics of plants in secondary forests and thus the conservation and recovery of tropical forests.

Species richness and diversity of ants interacting with diaspores was similar in all successional stages of forests. This contrasts to the reduced richness and diversity of the entire ground foraging ant fauna in secondary forests of the Atlantic forest in Southern Brazil (Bihn et al. 2008, 2010). Ant species interacting with diaspores accounted for an estimated $15 \%$ of the total species pool in the region (Bihn et al. 2010). Many ant species we found interacting

TABLE 2

Results of a two-factor nested ANOVA and test for linear trend on the effects of successional stage on diaspore removal rates with three replicated sites

\begin{tabular}{lcccc}
\multicolumn{1}{c}{ Source of variation: } & df & MS & F & p \\
Successional stage & 3 & 0.97 & 2.49 & 0.13 \\
Linear trend (successional stage) & 1 & 2.81 & 25.37 & $<0.001$ \\
Site (successional stage) & 8 & 0.39 & 3.48 & $<0.001$ \\
Error & 227 & 0.11 & & \\
\hline
\end{tabular}


with diaspores were relatively common in the study region (JH Bihn, unpublished results), especially species of Pheidole which accounted for the majority of ant-diaspore interactions in our and other studies in neotropical forests (Pizo et al. 1998, Pizo \& Oliveira 2000, Passos \& Oliveira 2003, Fornara \& Dalling 2005). All of the five most common species at diaspore depots, which accounted together for the majority of the observed ant-diaspore interactions, were present in at least two successional stages. In addition, interactions between ants and diaspores are mostly facultative and often involve ants with omnivorous diets (Pizo \& Oliveira 2000, Passos \& Oliveira 2003). Therefore, the habitat specialization of ants interacting with diaspores seems to be relatively low, which might indicate that the guild of ant species interacting with diaspores is rather resistant to habitat disturbance.

The behaviour of ants towards diaspores changed along the gradient of forest succession. In all stages of forest succession removal of the fleshy part of the diaspore in situ was the most common behaviour but the proportion of diaspores entirely removed increased from early to late successional stages. Both behaviours, seed cleaning and removal of diaspores, have implications for seed fate and plant establishment. Seed cleaning results in higher germination rates due to reduced fungal attack (Ohkawara \& Akino 2005, Christianini et al. 2007) but seeds remain available for other guilds of seed predator, e.g. rodents, marsupials and birds. Diaspore removal often leads to seed predation but a small number of seeds are left intact and are transported to protected microsites with favourable conditions for germination (Levey \& Byrne 1993, Pizo 2008). Because we did not track the fate of diaspores we cannot infer about the proportion of diaspores that reached favourable microsites for germination. Levey \& Byrne (1993) estimated that up to $39 \%$ of removed seeds are deposited in microsites with favourable conditions for germination, and Pizo (2008) found 93\% of diaspores deposited in favourable conditions, e.g. inside ant nests. If the proportion of seeds that reach favourable microsites for germination after seed removal is similar among successional stages, the increased seed removal in late successional stages could result in more seeds in microsites important for the recruitment of plant populations. It seems worth investigating in further studies, whether changes in the behaviour of ants towards diaspores in different successional stages of forests influence the number of seeds that become established as seedlings.

Diaspore removal rates were lower in young secondary than in old-growth forests and gradually increased with the age of secondary forests. Studies on invertebrate diaspore removal in different successional stages of tropical forests are few and report contradictory results. Notman \& Gorchov (2001) found higher removal rates in mature forests but other studies report higher removal rates in secondary forests than in old-growth forests (PeñaClaros \& de Boo 2002, Andresen et al. 2005, Zelikova \& Breed 2008). However, removal rates are not directly comparable among these investigations because each study uses a different set of diaspore species in the experiments and it has been demonstrated that removal rates of diaspores depend on diaspores identity (Notman \& Gorchov 2001, Pizo \& Oliveira 2001).

What are the implications of the observed changes of the behaviour of ants towards diaspores and the increased diaspore removal rates during forest regeneration? The most likely fate of removed diaspore is predation. However, various studies have documented that ants transport undamaged diaspores to safe and favourable microsites for germination (Leyey \& Byrne 1993, Pizo 2008). Although this outcome of ant-diaspore interactions might be rare, it might still be important for the recruitment of plant populations (Levey \& Byrne 1993). This is especially true for the interactions of ants and non-myrmechochorous diaspores in tropical forests, which are still largely unexplored (Pizo et al. 1998, Passos \& Oliveira 2003). Lower removal rates in young secondary forests could potentially increase sibling competition among seedlings and thus have negative effects on the recruitment of plant populations, slowing down 
the regeneration of these forests. Only careful tracking of diaspore fate, dispersal distance and germination success can illuminate the benefits and costs for the recruitment of the involved plants. The small diaspores, with which ants typically interact, are difficult to track in the opaque medium of the leaf litter in tropical forests but such studies seem worthwhile especially in the context of forest regeneration.

\section{ACKNOWLEDGMENTS}

This study was financially supported by Brazilian Research Council (CNPq) (Solobioma Project, 690148/01-1), the German Federal Ministry of Education and Research (BMBF project number 01LB0201), and the Fundação O Boticário de Proteção à Natureza. We thank the support of the SPVS for allowing us to work at Cachoeira Nature Reserve and their staff for field work assistance. Márcia C. $\mathrm{M}$. Marques received a productivity grant from CNPq (Process 308597/2008-7).

\section{RESUMEN}

Las interacciones entre animales y plantas son importantes para la recuperación de la diversidad y los procesos en los bosques secundarios, los cuales cada vez más tienden a dominar el paisaje tropical. Nosotros utilizamos una combinación de métodos experimentales y observaciones para estudiar las interacciones entre hormigas y diásporas a través de un gradiente de sucesión en los bosques del sur de Brasil, entre agosto 2007 y abril 2008. Además de las tasas de eliminación de diásporas, evaluamos la riqueza de especies, la diversidad y el comportamiento de las hormigas que interactúan con las diásporas, con tres repeticiones por sitio de cuatro estadios de sucesión del bosque. Se registraron 22 especies de hormigas que interactúan con diásporas (se estima un $15 \%$ del total de especies en la región). La riqueza y diversidad de especies no vario entre las etapas de sucesión, pero el comportamiento de las hormigas hacia las diásporas cambio con la edad de los bosques secundarios. En las etapas sucesionales avanzadas del bosque la eliminación de diásporas fue más común que en las etapas tempranas. En concordancia, las tasas de eliminación de diásporas fueron menores en la etapa más temprana de la sucesión de bosques secundarios y aumenta con la edad de los mismos. Estos resultados indican que las interacciones hormigasdiásporas en los bosques secundarios son alteradas y las menores tasas de extracción en los bosques secundarios es probable que limiten el reclutamiento de las poblaciones de plantas durante la sucesión secundaria.

Palabras clave: interacciones planta-hormiga, recuperación del bosque, dispersión de semillas, depredación de semillas, sucesión, bosques tropicales secundarios.

\section{REFERENCES}

Andresen E., L. Pedroza-Espino, E.B. Allen \& D.R. PéresSalicrup. 2005. Effects of selective vegetation thinning on seed removal in secondary forest succession. Biotropica 37: 145-148.

Armbrecht, I., L. Rivera, I. Perfecto. 2004. Reduced diversity and complexity in the leaf-litter ant assemblage of Colombian coffee plantations. Cons. Biol. 19: 897-907.

Beattie, A.J. 1985. The evolutionary ecology of antplant mutualisms. Cambridge University, Cambridge, United Kingdom.

Bihn, J.H., M. Verhaag, M. Brändle \& R. Brandl. 2008. Do secondary forests act as refuges for old growth forest animals? Recovery of ant diversity in the Atlantic forest of Brazil. Biol. Conserv. 141: 733-743.

Bihn, J.H., G. Gebauer \& R. Brandl. 2010. Loss of functional diversity of ant assemblages in secondary tropical forests. Ecology 91: 782-792.

Chazdon, R.L. 2003. Tropical forest recovery: legacies of human impact and natural disturbances. Perspect. Plant. Ecol. 6: 51-71.

Chazdon, R.L., C.A. Peres, D. Dent, D. Sheil, A.E. Lugo, D. Lamb, N.E. Stork \& S.E. Miller. 2009. The potential for species conservation in tropical secondary forests. Conserv. Biol. 23: 1406-1417.

Christianini, A.V. \& M. Galetti. 2007. Spatial variation on pos-dispersal seed removal in an Atlantic Forest: Effect of habitat, location and guilds of seed predators. Acta Oecol. 32: 328-336.

Christianini, A.V., A.J. Mayhe-Nunes \& P.S. Oliveira. 2007. The role of ants in the removal of non-myrmecochorous diaspores and seed germination in a Neotropical savanna. J. Trop. Ecol. 23: 343-351.

Clark, D.B. 1996. Abolishing virginity. J. Trop. Ecol. 12: 735-739.

Dunn, R.R. 2004. Recovery of faunal communities during tropical forest regeneration. Conserv. Biol. 18: 302-309. 
FAO. 2007. State of the world's forests. Food and Agriculture Organization of the United Nations, Rome, Italy.

Ferretti, A.R. \& R.M. Britez. 2006. Ecological restoration, carbon sequestration and biodiversity conservation: The experience of the Society for Wildlife Research and Environmental Education (SPVS) in the Atlantic Rain Forest of Southern Brazil. J. Nat. Conserv. 14: 249-259.

Flores, E. 1993. Hyeronima alchornoides, Alemão. Seeds and trees of the Neotropics Part II 514-17. Academia Nacional de Ciencias de Costa Rica, Costa Rica.

Fornara, D.A. \& J.W. Dalling. 2005. Post-dispersal removal of seeds of pioneer species from five Panamanian forests. J. Trop. Ecol. 21: 79-84.

Frankie, G.W., H.G. Baker \& P.A. Opler. 1974. Comparative phenological studies of trees in tropical wet and dry forests in the lowlands of Costa Rica. J. Ecol. 62: 881-913.

Gove, A.D., J.D. Majer \& R.R. Dunn. 2007. A keystone ant species promotes seed dispersal in a diffuse mutualism. Oecologia 153: 687-697.

Guariguata, M.R. \& R. Ostertag. 2001. Neotropical secondary forest succession: changes in structural and functional characteristics. For. Ecol. Manage. 148: 185-206.

Hobbs, R.J., S. Arico, J. Aronson, J.S. Baron, P. Bridgewater, V.A. Cramer, P.R. Epstein, J.J. Ewel, C.A. Klink, A.E. Lugo, D. Norton, D. Ojima, D.M. Richardson, J.B. Sanderson, F. Valladares, M. Vilà, R. Zamora \& M. Zobel. 2006. Novel ecosystems: theoretical and management aspects of the new ecological world order. Global Ecol. Biogeogr. 15: 1-7.

Holl, K.D., M.E. Loik, E.H.V. Lin \& I.A. Samuels. 2000 Tropical Montane forest restoration in Costa Rica: Overcoming barriers to dispersal and establishment. Restor. Ecol. 8: 339-349.

Howe, H.F. \& J. Smallwood. 1982. Ecology of seed dispersal. Annu. Rev. Ecol. Syst. 13: 201-228.

Hulme, P.E. 1998. Post-dispersal seed predation: consequences for plant demography and evolution. Perspect. Plant. Ecol. 1: 32-46.

IPARDES. 1991. Diagnóstico físico-ambiental da Serra do Mar: área Sul. IPARDES, Curitiba, Paraná, Brazil.

Kaspari, M. 1993. Removal of seeds from neotropical frugivores feces: ants responses to seed number. Oecologia 95: 81-88.
Koh, L.P., R.R. Dunn, N.S. Sodhi, R.K. Colwell, H.C. Proctor \& V.S. Smith. 2004. Species coextictions and the biodiversity crisis. Science 305: 1632-1634.

Krebs, C. 1989. Ecological methodology. Harper Collin, New York, New York, USA.

Levey, D.J. \& M.M. Byrne. 1993. Complex ant-plant interactions: rain-forest ants as secondary dispersers and postdispersal seed predators. Ecology 74: 1802-1812.

Manzaneda, A.J. \& P.J. Rey. 2008. Geographic variation in seed removal of a myrmecochorous herb: Influence of variation in functional guild and species composition of the disperser assemblage through spatial and temporal scales. Ecography 31: 583-597.

Notman, E. \& D.L. Gorchov. 2001. Variation in postdispersal seed predation in mature Peruvian lowland tropical forest and fallow agricultural sites. Biotropica 33: 621-636.

Ohkawara, K. \& T. Akino. 2005. Seed cleaning behavior by tropical ants and its anti-fungal effect. J. Ethol. 23: 93-98.

Passos, L. \& P.S. Oliveira. 2003. Interactions between ants, fruits and seeds in a restinga forest in south-eastern Brazil. J. Trop. Ecol. 19: 261-270.

Peña-Claros, M. \& H. De Boo. 2002. The effect of forest successional stage on seed removal of tropical rain forest tree species. J. Trop. Ecol. 18: 261-274.

Pfeiffer, M., J. Nais \& K.E. Linsenmair. 2006. Worker size and seed size selection in 'seed'-collecting ant ensembles (Hymenoptera: Formicidae) in primary rain forests on Borneo. J. Trop. Ecol. 22: 685-693.

Pizo, M.A., L. Passos \& P.S. Oliveira. 1998. Ants and seeds of a nonmyrmecochorous neotropical tree, Cabralea canjerana (Meliaceae), in the Atlantic forest of southeast Brazil. Am. J. Bot. 85: 669-674.

Pizo, M.A. \& P.S. Oliveira. 2000. The use of fruits and seeds by ants in the Atlantic forest of southeast Brazil. Biotropica 32: 851-861.

Pizo, M.A. \& P.S. Oliveira. 2001. Size and lipid content of nonmyrmechorous diaspores: Effects on the interaction with litter-foraging ants in the Atlantic rain forest of Brazil. Plant Ecol. 157: 37-52.

Pizo, M.A. 2008. The use of seeds by a twig-dwelling ant on the floor of a tropical rain forest. Biotropica 40: 119-121. 
Rico-Gray, V. \& P.S. Oliveira. 2007. The ecology and evolution of ant-plant interactions. The University of Chicago, Chicago, Illinois, USA.

Sarmiento, F.O. 1997. Arrested succession in pastures hinders regeneration of Tropandean forests and shreds mountain landscapes. Environ. Conserv. 24: 14-23.

Silva, R.R., R.S.M. Feitosa \& F. Eberhardt. 2007. Reduced ant diversity along a regeneration gradient in the southern Brazilian Atlantic Forest. For. Ecol. Manage. 240: 61-69.

Silveira, K., J.B. Skillman \& J.W. Dalling. 2003. Seed germination, seedling growth and habitat partitioning in two morphotypes of the tropical pioneer tree Trema micrantha in a seasonal forest in Panama. J. Trop. Ecol. 19: 27-34.

Theilade, I. \& L. Petri. 2003. Conservation of tropical trees ex situ through storage and use. Guidelines and Technical Notes No. 65. Danida Forest Seed Centre, Humlebaek, Denmark.
Thompson, D.B., J.H. Brown \& W.D. Spencer. 1991. Indirect facilitation of granivorous birds by desert rodents: experimental evidence from foraging patterns. Ecology 72: 852-863.

Vander Wall, S.B. \& W. Longland. 2004. Diplochory: Are two seed dispersers better than one? Trends Ecol. Evol. 19: 155-161.

Wang, B.C. \& T.B. Smith. 2002. Closing the seed dispersal loop. Trends Ecol. Evol. 17: 379-387.

Wright, S.J. 2005. Tropical forests in a changing environment. Trends Ecol. Evol. 20: 553-560.

Wright, S.J. \& H.C. Muller-Landau. 2006. The future of tropical forest species. Biotropica 38: 287-301.

Zelikova, T.J. \& M.D. Breed. 2008. Effects of habitat disturbance on ant community composition and seed dispersal by ants in a tropical dry forest in Costa Rica. J. Trop. Ecol. 24: 309-316. 